\title{
Popcorn genotypes resistance to fall armyworm
}

\author{
Nádia Cristina de Oliveira ${ }^{1 *}$ Andréia Kazumi Suzukawa ${ }^{2}$ Carolina Bertuzzi Pereira $^{2}$ \\ Hayssa Vilela Santos ${ }^{1}$ Aldo Hanel ${ }^{1}$ Fernando Alves de Albuquerque $^{3}$ Carlos Alberto Scapim ${ }^{2}$
}

${ }^{1}$ Centro Universitário Integrado, Rodovia BR 158 km 207, 87300-970, Campo Mourão, PR, Brasil. E-mail: nadiac.oliveira@hotmail.com. ${ }^{*}$ Corresponding author.

${ }^{2}$ Programa de Pós-graduação em Agronomia, Universidade Estadual de Maringá (UEM), Maringá, PR, Brasil.

${ }^{3}$ Departamento de Agronomia, Universidade Estadual de Maringá (UEM), Maringá, PR, Brasil.

\begin{abstract}
The aim of this study was to evaluate popcorn genotypes for resistance to the fall armyworm, Spodoptera frugiperda. The experiment used a completely randomized design with 30 replicates. The popcorn genotypes Aelton, Arzm 05 083, Beija-Flor, Colombiana, Composto Chico, Composto Gaúcha, Márcia, Mateus, Ufvm Barão Viçosa, Vanin, and Viviane were evaluated,along with the common maize variety Zapalote Chico. Newly hatched fall armyworm larvae were individually assessed with regard to biological development and consumption of food. The data were subjected to multivariate analyses of variance and genetic divergence among genotypes was evaluated through the clustering methods of Tocher based on generalized Mahalanobis distances and canonical variable analyses. Seven popcorn genotypes, namely, Aelton, Arzm 05 083, Composto Chico, Composto Gaúcha, Márcia, Mateus, and Viviane,were shown to form a cluster (cluster I) that had antibiosis as the mechanism of resistance to the pest. Cluster I genotypes and the Zapalote Chico genotype could be used for stacking genes for antibiosis and non-preference resistance.

Key words: antibiosis, nutrition index, plant breeding, Spodoptera frugiperda.
\end{abstract}

Genótipos de milho pipoca resistentes à lagarta-do-cartucho

RESUMO: O objetivo do estudo foi avaliar genótipos de milho pipoca para resistência à lagarta-do-cartucho, Spodoptera frugiperda. O experimento foi conduzido em delineamento inteiramente casualizado com 30 repetiçoes. Foram avaliados os genótipos de milho pipoca Aelton, Arzm 05 083, Beija-Flor, Colombiana, Composto Chico, Composto Gaúcha, Márcia, Mateus, Ufvm Barão Viçosa, Vanin, Viviane e Zapalote Chico. Larvas recém-eclodidas foram individualizadas para avaliação do desenvolvimento biológico e consumo alimentar. Os dados foram submetidos à análise multivariada de variância e a divergência genética entre genótipos foi avaliada através dos métodos de agrupamento de Tocher, com base na distância generalizada de Mahalanobis e análise de variáveis canônicas. Sete genótipos, Aelton, Arzm 05 083, Composto Chico, CompostoGaúcha, Márcia, Mateus e Viviane formaram um cluster (cluster I) que apresentaram antibiose com o mecanismo de resistência à praga. Os genótipos do cluster I e Zapalote Chico podem ser usados para empilhar genes para resistência por antibiose e não-preferência.

Palavras-chave: antibiose, melhoramento de plantas, Spodoptera frugiperda.

\section{INTRODUCTION}

Popcorn (Zea mays L. ssp. mays) is a specialized type of maize in which harvested kernels have the ability to form flakes when heated; this trait distinguishes popcorn from other types of corn (JELE, 2014). In Brazil, there is an increasing demand for popcorn (MOTERLE et al., 2012); however, breeding new varieties is hampered by the narrow genetic base present in the germplasm (PAJIC et al., 2008, SANCHES, 2011). As a consequence, agronomic performance for traits of interest, such as reduced susceptibility to pests and diseases, are poorer in Brazil (LI et al., 2008).

One of the important phytosanitary problems faced by popcorn is the fall armyworm (FAW), Spodoptera frugiperda (J.E. Smith) (Lepidoptera: Noctuidae), apolyphagous noctuid that is widespread in Latin America and the United States (CLARK et al., 2007). This major pest of maize can cause significant damage to crops and is difficult to control (SANTOS et al., 2004). 
Infestation with FAW reduce grain yields by about $20 \%$, although if uncontrolled, losses can be up to $73 \%$ (ARIAS et al., 2011). The pest is responsible for an annual loss of crops valued at approximately 500 million dollars (SÁ et al., 2009).

The principal approach to control of FAW is use of chemical insecticides. However, these treatments are costly and may not reach larvae inside the maize whorl or the corn cob; multiple applications are frequently required in consequence. The risk of environmental contamination by insecticides is also a concern (CUNHA et al., 2008). An alternative approach to pest control is the development of plant resistance. Resistance may cause adverse effects to the insects (antibiosis) or make one plant less preferred than another for feeding (non-preference) (SMITH, 2005).

Although, there are studies showing that resistant plants interfere with the development and behaviour of S. frugiperda (LIMA et al., 2006), there is little research on this pest in popcorn (CRUBELATIMULATI et al., 2014).

The influence that different genotypes of popcorn have on development of $S$. frugiperda may reveal an important role in selection of resistant materials to this pest. Thus, the objective of this research was to characterize sources of resistance in popcorn in relation to $S$. frugiperda that could be used in future plant breeding programs.

\section{MATERIALS AND METHODS}

The experiments were carried out in the Entomology Laboratory and in the greenhouse of the University Center Integrated, Campo Mourão, Paraná State. Seeds of various popcorn varieties were obtained from the Special Maize Breeding Program developed by the State University of Maringá-UEM. The popcorn genotypes used here were Aelton, Arzm 05 083, Beija-Flor, Colombiana, Composto Chico, Composto Gaúcha, Márcia, Mateus, Ufvm Barão Viçosa, Vanin, and Viviane; as a comparison, we also used the common maize variety Zapalote Chico.

Seeds were placed in fertilized soil in $8 \mathrm{~L}$ polyethylene pots. After germination, the plants were kept in the green house under controlled irrigation conditions. Leaf samples were collected from plants during the V6-V8 phenological stages (six to eight fully extended leaves). In the laboratory, experiment was performed using experiment was also performed using a climatic chamber (BOD) under controlled conditions (temperature of $25 \pm 1^{\circ} \mathrm{C}$, relative humidity of $70 \pm 10 \%$, and photophase of 12 hours). Acompletely randomized design was used in the experiment with 12 treatments and 30 replicates; individual larvae were considered a replicate.

Eggs of $S$. frugiperda close to hatching, from insects fed with an artificial diet (GREENE et al., 1976), were obtained from PROMIP Company. Subsequently, newly hatched caterpillar larvae were individually transferred to transparent acrylic plates $(9.0 \mathrm{~cm}$ in diameter and $1.5 \mathrm{~cm}$ in height) lined with moistened filter paper at the bottom. The caterpillars were fed with leaf sections taken from the middle third of maize plants at phenological stages V6 to V8. Food was renewed daily and the amount of leaf provided was altered during the development of the caterpillars, in order to avoid any insufficiency of food.

After formation, the pupae were kept in acrylic plates $(9.0 \mathrm{~cm}$ in diameter and $1.5 \mathrm{~cm}$ in height) lined with moistened filter paper until adult emergence. After emergence, the sex of the adults was determined and the insects were transferred to oviposition cages made of polyvinyl chloride (PVC) tubes, $10 \mathrm{~cm}$ in diameter by $20 \mathrm{~cm}$ in height, with perforated PVC caps. Cages were lined internally with sulphite paper to allow oviposition from females. For the nutrition of adults, a container with cotton soaked in $10 \%$ sucrose solution was placed inside the cages. Eggs'mass were collected daily and the number of eggs was counted using a stereo microscope at $40 \times$ magnification; the eggs were kept on acrylic plates lined with filter paper.

The leaf area consumption (LAC) of the different genotypes was evaluated daily throughout the larval phase. Determination of LAC was defined as the difference between leaf area offered and leaf area consumed after 24 hours. For measurements of leaf areas, a CI-202 Portable Laser Leaf Area Meter was used.

Determination of fresh leaf mass, before and at 24 hours after supply to the caterpillars, was determined using an analytical balance. For each genotype, three plates containing a leaf section (control) were maintained daily without a caterpillar to determine loss of water. In the same way as the other leaves, these were also weighed before and at $24 \mathrm{~h}$ to calculate the correction factor.

Caterpillars were each weighed daily from the 5th day of life. The daily mass of each caterpillar is cumulative; therefore, the weight on the last day of the larval phase is equivalent to the total mass gain or final mass of the caterpillar. The mean mass of larvae (MM) during the larval period was obtained by the following calculation: $\mathrm{MM}=\Sigma \mathrm{M}$ daily/T, where $\mathrm{M}$ $=$ daily mass of caterpillars, and $\mathrm{T}=$ duration of the larval period in days. Excrement from each caterpillar 
was collected and weighed daily throughout the larval period to obtain the total mass of excreta produced. Daily measurement of excreta produced was also performed after the fifth day of life. Food consumption and utilization indexes were calculated from the data of leaf mass, leaf area, caterpillar mass, and faecal mass, as proposed by SCRIBER \& SLANSKY JUNIOR(1981):

- Relative consumption rate: $\mathrm{RCR}=\mathrm{E} /(\mathrm{WxT})$

- Relative metabolic rate: $\mathrm{RMR}=\mathrm{M} \times(\mathrm{MMxT})$

- Relative growth rate: $\mathrm{RGR}=\mathrm{FM}(\mathrm{MMxT})$

- Efficiency in conversion of ingested food: $\mathrm{ECIF}=(\mathrm{FM} / \mathrm{E}) \times 100$

- Apparent digestibility: $\mathrm{AD}=(\mathrm{A} / \mathrm{E}) \times 100$,

where $\mathrm{T}$ is the duration of larval period, $\mathrm{E}$

is the weight of food consumed during $\mathrm{T}, \mathrm{W}$ is the daily mass of caterpillars, $\mathrm{MM}$ is the mean mass of caterpillars during T, FM is the final mass of caterpillars, and $\mathrm{F}$ is faeces (i.e., the undigested food and excretion products during $\mathrm{T}$ ), $\mathrm{A}$ is assimilated food during $\mathrm{T}=\mathrm{E}-\mathrm{F}, \mathrm{M}$ is the food metabolized during $\mathrm{T}=\mathrm{A}-\mathrm{FM}$.

The data were analysed statistically using a multivariate analysis of variance (MANOVA) with Wilks criterion $(\mathrm{p} \leq 0.05)$ to test the hypothesis of differences between mean vectors of each genotype. This analysis was conducted using the GLM procedure with the option MANOVA in SAS (SAS INSTITUTE, 2011).Then, a multicollinearity diagnosis was performed on the genotypic correlation matrix, in order to identify possible variables that cause greater problems of multicollinearity. Genetic divergence among the genotypes was evaluated through the clustering methods of Tocher based on the generalized distance of Mahalanobis (1936) and canonical variable analysis. Similarity between genotypes was also demonstrated using canonical variables by graphical dispersion. The Mahalanobis distance matrix and the Tocher optimization method were performed using the Genes computational program (CRUZ, 2013). The R (R Development Core Team 2014) program was used to analyse canonical variables using the package candisc function.

\section{RESULTS AND DISCUSSION}

The test of significance based on Wilk's (Lambda) criterion showed significant differences among genotypes for all the characteristics evaluated (p-value $<0.0001$ ), indicating the existence of significant genetic variability.

Before the canonical correlation analysis, the multicollinearity was evaluated by the condition number of the genetic correlation matrix. The concomitant inclusion of all analysed characteristics caused severe multicollinearity in genotypic correlation matrix. After elimination of these variables from the analysis, moderate multicollinearity was provided by MM, LAC, RCR, ECIF, RMR, RGR, and AD.

A cluster analysis using the Mahalanobis distances showed that the twelve genotypes could be grouped into three clusters. Cluster I was the largest with seven genotypes: Aelton, Arzm 05 083, Composto Chico, CompostoGaúcha, Márcia, Mateus, and Viviane.Cluster II had four genotypes: UfvmBarãoViçosa, Beija-Flor, Colombiana, and Vanin. Minimum single genotype, Zapalote Chico, was present in cluster III (Table 1).

The smallest LAC recorded was found for the Zapalote Chico genotype (cluster III, Table 1) with a low relative consumption rate (RCR); these data confirm the previously reported resistance of

Table 1 - Clusters with similar behaviour patterns established by the Tocher Optimization method, based on Mahalanobis distance between 12 maize genotypes and their respective means and standard deviations per group of seven response variables.

\begin{tabular}{|c|c|c|c|c|c|c|c|c|}
\hline \multirow{2}{*}{ Cluster } & \multirow{2}{*}{ Genotypes $^{1}$} & \multicolumn{7}{|c|}{-Characteristics ${ }^{2}$} \\
\hline & & MM (g) & $\operatorname{LAC}\left(\mathrm{cm}^{2}\right)$ & RCR (g/g day) & ECIF (\%) & RMR (\%) & RGR (\%) & $\mathrm{AD}(\%)$ \\
\hline I & $1,2,6,7,8,9,11$ & $\begin{array}{c}0.122 \pm \\
0.016\end{array}$ & $\begin{array}{c}234.313 \pm \\
27.421\end{array}$ & $\begin{array}{c}1.581 \\
\pm 0.179\end{array}$ & $\begin{array}{c}11.476 \pm \\
2.058\end{array}$ & $\begin{array}{c}3.894 \pm \\
1.379\end{array}$ & $\begin{array}{c}1.090 \pm \\
0.305\end{array}$ & $\begin{array}{c}51.641 \pm \\
5.938\end{array}$ \\
\hline II & $3,4,5,10$ & $\begin{array}{c}0.129 \pm \\
0.016\end{array}$ & $\begin{array}{c}154.290 \pm \\
23.289\end{array}$ & $\begin{array}{c}1.257 \pm \\
0.213\end{array}$ & $\begin{array}{c}16.678 \pm \\
3.231\end{array}$ & $\begin{array}{c}2.750 \pm \\
1.338\end{array}$ & $\begin{array}{c}1.059 \pm \\
0.273\end{array}$ & $\begin{array}{c}57.882 \pm \\
9.463\end{array}$ \\
\hline III & 12 & $\begin{array}{c}0.133 \pm \\
0.023\end{array}$ & $\begin{array}{c}124.610 \pm \\
16.608\end{array}$ & $\begin{array}{l}1.234 \pm \\
0.275\end{array}$ & $\begin{array}{c}18.166 \pm \\
4.947\end{array}$ & $\begin{array}{c}4.193 \pm \\
1.997\end{array}$ & $\begin{array}{c}1.338 \pm \\
0.350\end{array}$ & $\begin{array}{c}70.926 \pm \\
8.168\end{array}$ \\
\hline
\end{tabular}

11: Aelton, 2: Arzm 05 083, 3: Ufvm Barão Viçosa, 4: Beija-Flor, 5: Colombiana, 6: Composto Chico, 7: Composto Gaúcha, 8: Márcia, 9; Mateus, 10: Vanin, 11: Viviane, 12: Zapalote Chico. ${ }^{2} \mathrm{MM}$ : mean mass of larvae; LAC: leaf area consumption; RCR: relative consumption rate; ECIF: efficiency in conversion of ingested food; RMR: relative metabolic rate; RGR: relative growth rate; AD: apparent digestibility. 
this genotype to $S$. frugiperda as a non-preference type (VIANA \& POTENZA, 2000). By definition, non-preference occurs when a plant is eaten to a lesser extent by an insect than other plants in equal conditions. Traits such as the physical properties of the leaves (thickness, hardness, texture, epicuticular wax, and surface hairiness), chemical properties (allelochemical), and nutritional properties influence the amount of leaf consumed by an insect (SMITH, 2005, HANLEY et al., 2007).

Results obtained for nutritional indexes indicated that antibiosis resistance characteristics were present in genotypes from cluster I, namely, Aelton, Arzm 05 083, Composto Chico, Composto Gaúcha, Márcia, Mateus, and Viviane (Table 1). For these genotypes, caterpillars had a significantly higher relative consumption rate (RCR), which represents the amount of food that the insect consumes (milligram of body weight per day) but lower efficiency of conversion of ingested food (ECIF) and lower mean mass of larvae (MM) compared. Thus, caterpillars on these genotypes appeared to have a lower capacity for using ingested food for growth. Antibiosis resistance induced insects to consume greater quantities of food as a compensatory means to guarantee survival when the food source is inadequate; however, this increased food intake disturbs biological development and causes weight reduction, longer life cycle, altered fertility, and mortality (SMITH, 2005, LIMA et al., 2006). Antibiosis may be due to the presence of toxic compounds or developmental inhibitors, or to nutritional imbalance or lack of essential nutrients in the plant (SMITH, 2005). The lowest values of apparent digestibility (AD) also occurred in genotypes in cluster I. The AD values represent how much food was effectively used by the insect for growth and metabolism. Genotypes with low AD values are considered less efficient because they were less used by caterpillars for growth and metabolism. Contents and proportions of biochemical constituents of food are essential characteristics of dietary efficiency. Nutritional imbalance, water deficiency, and presence of allelochemicals are factors which can reduce digestibility (SMITH, 2005, FÜRSTENBERGHÄGG et al., 2013).

The genotypes Ufvm Barão Viçosa, Beija-Flor, Colombiana, and Vanin (cluster II, Table 1) favoured the development of $S$. frugiperda; caterpillars fed on the leaves of these plants had the lowest relative metabolic rate (RMR) due the greater ease of converting assimilated food into larval biomass. Likewise, for these genotypes; the relative consumption rate (RCR) was low, the efficiency in conversion of ingested food (ECIF) was satisfactory. A plant is considered adequate for feeding an insect when it shows an inverse correlation between food consumption and efficiency of use (Table 1) (CRÓCOMO \& PARRA, 1985).

In the canonical correlation analysis, the first two canonical variables explained approximately $89.73 \%$ of the total available variation in the data (73.74\% for the first canonical variable, $15.99 \%$ for the second) (Table 2). Thus, the analysis of genetic divergence by graphic dispersion was satisfactory, based on the scores of the two canonical variables (Figure 1).

The first component, i.e., the abscissa axis, was associated with leaf area consumed (LAC), relative consumption rate (RCR), and efficiency in conversion of ingested food (ECIF); the second component, the coordinate axis, was associated with relative metabolic rate (RMR) and relative growth rate (RGR) (Figure 1).

Table 2 - Estimates of eigenvalues and weighting coefficients (eigenvectors) of the seven characteristics evaluated in 12 maize genotypes.

\begin{tabular}{|c|c|c|c|c|c|c|c|c|c|}
\hline \multirow{2}{*}{$\begin{array}{l}\text { Canonical } \\
\text { Variable }\end{array}$} & \multirow{2}{*}{ Eigenvalue } & \multirow{2}{*}{$\begin{array}{c}\text { Cumulative } \\
\text { variance }(\%)\end{array}$} & \multicolumn{7}{|c|}{ 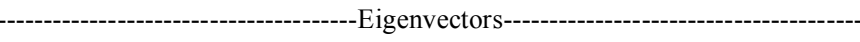 } \\
\hline & & & $\mathrm{MM}^{1}$ & $\mathrm{LAC}^{1}$ & $\mathrm{RCR}^{1}$ & $\mathrm{ECIF}^{1}$ & $\mathrm{RMR}^{1}$ & $\mathrm{RGR}^{1}$ & $\mathrm{AD}^{1}$ \\
\hline CV1 & 6.022 & 73.74 & -0.08 & 1.06 & -0.20 & -1.13 & -0.72 & -0.16 & -0.55 \\
\hline $\mathrm{CV} 2$ & 1.306 & 89.73 & 0.24 & -0.84 & 1.15 & -0.52 & 0.33 & 1.08 & -0.97 \\
\hline CV3 & 0.572 & 96.73 & 1.11 & -0.56 & 0.06 & -0.21 & 0.65 & -1.19 & -1.25 \\
\hline CV4 & 0.111 & 98.08 & 0.85 & -0.18 & -0.03 & -1.27 & -0.25 & -0.52 & -0.10 \\
\hline CV5 & 0.084 & 99.11 & 0.59 & 0.30 & 0.95 & 2.05 & 0.67 & -1.16 & 1.09 \\
\hline CV6 & 0.056 & 99.80 & -0.85 & -0.29 & 0.30 & -1.03 & -1.33 & 1.04 & -0.28 \\
\hline CV7 & 0.017 & 100.00 & 0.66 & 0.20 & 0.30 & -0.64 & -1.51 & 0.63 & 0.45 \\
\hline
\end{tabular}

${ }^{1} \mathrm{MM}$ : mean mass of larvae; LAC: leaf area consumption; RCR: relative consumption rate; ECIF: efficiency in conversion of ingested food; RMR: relative metabolic rate; RGR: relative growth rate; AD: apparent digestibility. 


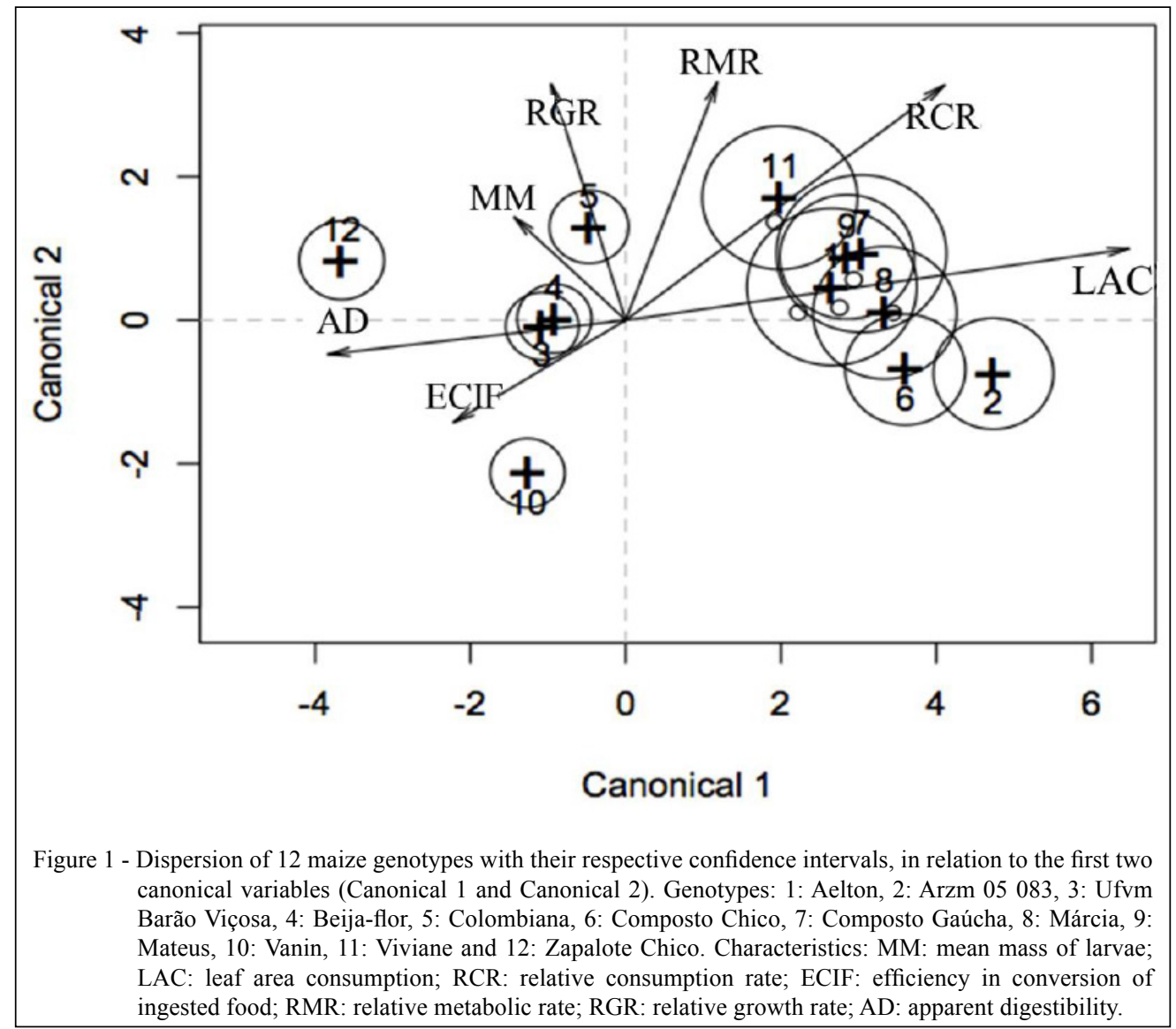

According to the scatter plots (Figure 1) the most similar genotypes are Aelton (1), Arzm 05 083 (2), Composto Chico (6), Composto Gaúcha (7), Márcia (8), Mateus (9), and Viviane (11); these genotypes were in cluster I using Tocher methods (Table 1).This group and Zapalote Chico (12) were the most dissimilar. Therefore, cluster I genotypes and Zapalote Chico have the potential to be used in genetic breeding to stack genes for antibiosis and non-preference resistance and, in consequence,to increase resistance to $S$. frugiperda.

\section{CONCLUSION}

Genotypes in cluster I, namely, Aelton, Arzm 0583, Composto Chico, Composto Gaúcha, Márcia, Mateus and Viviane showed antibiosis as a resistance mechanism to Spodoptera frugiperda. These genotypes have the potential to be used for future genetic breeding of popcorn maize.

The cluster genotypes I and Zapalote Chico have the potential to be used for stacking genes for antibiosis and non-preference resistance and, in consequence, to increase resistance.

\section{REFERENCES}

ARIAS, R.E.S. et al. First microsatellites from Spodoptera frugiperda (Lepidoptera: Noctuidae) and their potential use for population genetics. Annals of the Entomological Society of America, v.104, p.576-587, 2011. Available from: $<\mathrm{http}$ ://digitalcommons.unl.edu/cgi/viewcontent.cgi?article $=1$ 895\&context $=$ usdaarsfacpub $>$. Accessed: Jun. 04, 2017. doi: 10.1603/AN10135.

CLARK, P.L.et al. Population variation of Spodoptera frugiperda (J. E. Smith) in the Western Hemisphere. Journal of Insect Science, v.7, p.1-10, 2007. Available from: <https:// doi.org/10.1673/031.007.0501>. Accessed: Jun. 04, 2017. doi: 10.1673/031.007.0501.

CROCOMO, W.B.; PARRA J.R.P. Consumo e utilização de milho, trigo e sorgo por Spodoptera frugiperda (J.E. Smith, 1797) (Lepidoptera: Noctuidae). RevistaBrasileira de Entomologia, v. 29, n.2, p. $225-260,1985$.

CRUBELATI-MULATI, N.C. et al. Prospecting of popcorn hybrids for resistance to fall armyworm. Genetics and Molecular 
Research, v.13, n.3, p.6539-6547, 2014. Available from: <http:// www.funpecrp.com.br/gmr/year2014/vol13-3/pdf/gmr4989.pdf>. Accessed: May 24, 2017. doi: 10.4238/2014.August.26.4.

CRUZ, C.D. GENES - a software package for analysis in experimental statistics and quantitative genetics. Acta Scientiarum, v.35, n.3. p.271-276, 2013. Available from: $<$ http://periodicos.uem. br/ojs/index.php/ActaSciAgron/article/view/21251/0>. Accessed: May 24, 2017. doi: 10.4025/actasciagron.v35i3.21251.

CUNHA,U.S. et al. Resistance of corn genotypes for subtropical lowland cropping to fall armyworm Spodoptera frugiperda. Ciência Rural, v.38, n.4, p.1125-1128, 2008. Available from: $<$ http://www.scielo.br/scielo.php?script=sci_arttext\&pid=S0103$84782008000400034 \& \operatorname{lng}=$ en\&nrm=iso\&tlng $=\mathrm{pt}>$. Accessed: May 24, 2017. doi: 10.1590/S0103-84782008000400034.

FÜRSTENBERG-HÄGG, J.et al. Plant defense against insect herbivores. International Journal of Molecular Sciences, v.14, p.10242-10297, 2013. Available from: <http://www.mdpi. com/1422-0067/14/5/10242>. Accessed: May 24, 2017. doi: 10.3390/ijms 140510242 .

GREENE, G.L. et al. Velvet bean caterpillar: a rearing procedure and artificial medium. Journal of Economic Entomology, v.69, n.4, p.488-497, 1976. doi: 10.1093/jee/69.4.487.

HANLEY,M.E. et al. Plant structural traits and their role in antiherbivore defence. Perspectives in Plant Ecology, Evolution and Systematics, v.8, n.4, p.157-178, 2007. Available from: <http:// www.academia.edu/15373814/Plant_structural_traits_and_their_ role_in_anti-herbivore_defence $>$. Accessed: May 24, 2017. doi: $10.101 \overline{6} /$ j.ppees.2007.01.001.

JELE, P. et al. Assessment of popping ability of new tropical popcorn hybrids. Australian Journal of Crop Science, v.8, n.6, p.831- 839, 2014. Available from: <http://www.cropj.com/ derera_8_6_2014_831_839.pdf>. Accessed: Jun. 04, 2017.

LI, Y. et al. Identification of agronomically favorable quantitative trait loci alleles from a dent corn inbred Dan232 using advanced backcross QTL analysis and comparison with the F 2:3 population in popcorn. Molecular Breeding, v.21, n.1, p.1-14, 2008. Available from: $<$ https://link.springer.com/article/10.1007/ s11032-007-9104-z>.Accessed: May 24, 2017. doi: 10.1007/ s11032-007-9104-Z.

LIMA, W.N. Evaluation of a maize collection to Spodoptera frugiperda (Smith) (Lepidoptera: Noctuidae) resistance in laboratory. Acta Amazonica, v.36, n.2, p.147-150, 2006. Available from: $\quad<$ http://www.scielo.br/scielo.php?script=sci_arttext\&pid $=$ S0044-59672006000200003 $>$. Accessed: May 24, 2017. doi: 10.1590/S0044-59672006000200003.
MOTERLE, L.M. et al. Combining ability of popcorn lines for seed quality and agronomic traits. Euphytica, v.185, p.337-347, 2012. Available from: <https://link.springer.com/article/10.1007/ s10681-011-0458-2>. Accessed: May 25, 2017.doi: 10.1007/ s10681-011-0458-2.

PAJIC, Z. Popping volume and grain yield in diallel set of popcorn inbred lines. Genetika, v.40, n.3, p.249-260, 2008. Available from: $<$ https://doi.org/10.2298/GENSR0803249P>. Accessed: Mar. 25, 2017. doi: 10.2298/GENSR0803249P.

R FOUNDATION FOR STATISTICAL COMPUTING. A language and environment for statistical computing. Vienna: R Foundation for Statistical Computing, 2014. Available from: <http://www.rproject.org>. Accessed: Mar. 25, 2017.

SÁ, V.G.M. et al. Survival and larval development of Spodoptera frugiperda (J. E. Smith) (Lepidoptera: Noctuidae) on alternatives host. Neotropical Entomology, v.38, p.108-115, 2009. Available from: <http://dx.doi.org/10.1590/S1519-566X2009000100012>. Accessed: May 25, 2017. doi: 10.1590/S1519-566X200900010001.

SANCHES, R.E. et al. Genetic analysis of tropical rust resistance in popcorn lines. Ciência Rural, v.41, n.6, p.967-971, 2011. Available from: $<$ http://www.scielo.br/scielo.php?script=sci_artte xt\&pid=S0103-84782011000600008>. Accessed: May 25, 2017. doi: 10.1590/S0103-84782011000600008.

SANTOS, L.M. et al. Fertility and longevity of Spodoptera frugiperda (J. E. Smith) (Lepidoptera: Noctuidae) in corn genotypes. Ciência Rural, v.34, p.345-350, 2004. Available from: $<\mathrm{http}: / / \mathrm{www}$. scielo.br/scielo.php?script $=\mathrm{sci}$ arttext\&pid=S0103-84782004000200002>. Accessed: May 25, 2017. doi: 10.1590/S0103-84782004000200002.

SAS INSTITUTE. The SAS system for Windows. Release 9.4. Cary, NC: SAS Institute.

SCRIBER, J.M.; SLANSKY JÚNIOR, F. The nutritional ecology of immature insects. Annual Review of Entomology, v.26, n.1, p.183-211, 1981. Available from: <https://doi.org/10.1146/ annurev.en.26.010181.001151>. Accessed: Feb. 20, 2016. doi: 10.1146/annurev.en.26.010181.001151.

SMITH, C.M. Plant resistance to arthropods: Molecular and conventional approaches. Dordrecht: Springer, 2005. 423p.

VIANA, P.A.; POTENZA, M.R. Non-preference and antibiosis of fall armyworm for selected corn genotypes. Bragantia, v.59, n.1, p.27-33, 2000. Available from: <http://www.scielo.br/scielo. php? script $=$ sci_arttext\&pid $=$ S0006-87052000000100006\&lng $=$ en\&nrm=iso>. Accessed: May 25, 2017. doi: 10.1590/S000687052000000100006 